\title{
イオン照射を利用した成膜プロセスの評価法*
}

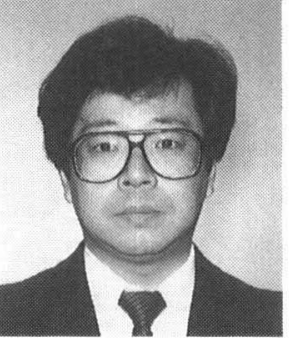

節原 裕一

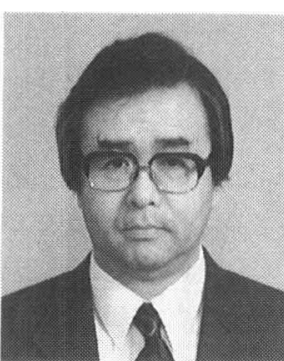

三宅 正司
節 原 裕 一**, 三 宅 正 司***

\section{Characterization of Ion-Assisted Deposition Processes for Surface Modifications*}

by Yuichi Setsuhara** and Shoji Miyake**

キーワード : 表面改質, イオンビーム支援蒸着, 物理蒸着, 計測, 粒子供給束

\section{1. はじめに}

高硬度, 耐磨耗性, 高耐食性, あるいは高誘電率等の 基材の保護・延命あるいは基材とは異なる機能性を基板 材料上に付与することを目的とした薄膜形成技術は，切 削工具から高温材料, 光学機器, 半導体にわたる広い産 業応用の可能性を秘めており，また，多くの工業分野で 実用化されてきている．特に，近年の機能材料創製ある いは超微細加工等の分野においては，基材を高温状態に 保ってプロセスを行うことによる基材の変形，不純物の 拡散等の弊害を避け高品質の薄膜を得るため, なるべく 低い基材温度での表面改質プロセスが求められている. この傾向は, ポリマー等を含む基材の多様化とともに顕 著になりつつある。このため, 従来のいわゆる熱加工あ るいは熱プロセスにかわって, 低い基材温度での非平衡 プロセスの研究が, 表面改質分野においてますます重要 となりつつある。また, 次世代のエンジニアリング材料 として注目されている立方晶窒化ホウ素等は, 高温高圧 下でのみ合成が可能な準安定化合物であり, その低温合 成にはイオン衝撃等による非平衡活性場を利用すること が不可欠となっている ${ }^{1,2)}$.このため, イオンビームある いは加速粒子ビームを用いた材料プロセスは, フラズマ および光プロセスとならんで, 非平衡場を利用した機能 性表面改質技術の重要な核の一つとして近年大いに注目 されている。本稿では, イオン照射効果を利用した表面 改質の研究あるいは実務にこれから入られる方々を念頭 に置き, 主としてイオンビームを用いた成膜プロセスに おける, 基本的なプロセスパラメータの評価方法につい て解説する。

\footnotetext{
*原稿受付 平成 9 年 2 月 24 日

** 大阪大学 Osaka University

***正 員 大阪大学 Member, Osaka University
}

\section{2. イオン照射を利用した表面改質プロセス}

イオン照射効果を利用したプロセスと関連する イオン-固体相互作用の関係を図 $1^{3}$ 示す. 関与する粒子 の運動エネルギーから分類すると，核子当たり 1-100 電 子ボトル $(\mathrm{eV})$ 程度の低エネルギーイオンを利用するイ オンビーム蒸着 (Ion Beam Deposition, IBD) およびク ラスターイオンビーム蒸着 (Ionized Cluster Ion Beam Deposition, ICBD), 数 $\mathrm{keV}$ 程度までのエネルギー領域 にあるイオンプレーティング (Ion Plating, IP) やスパッ タリング (Ion Beam Sputtering, IBS) 等のいわゆる物 理蒸着 (Physical Vapor Deposition, PVD), 数 $10 \mathrm{eV}$ か ら数 $10 \mathrm{keV}$ のイオンを照射しながら成膜を行うイオン ビーム支援蒸着法 (Ion Beam Assisted Deposition, IBAD ) 等がある.さらに高いエネルギー領域では, 数 $10 \mathrm{keV}$ から MeV 領域のイオン注入 (Ion Implantation）により半導体素子製造における不純物添加法ある いは各種材料の母材表面の改質技術として有効性が実証

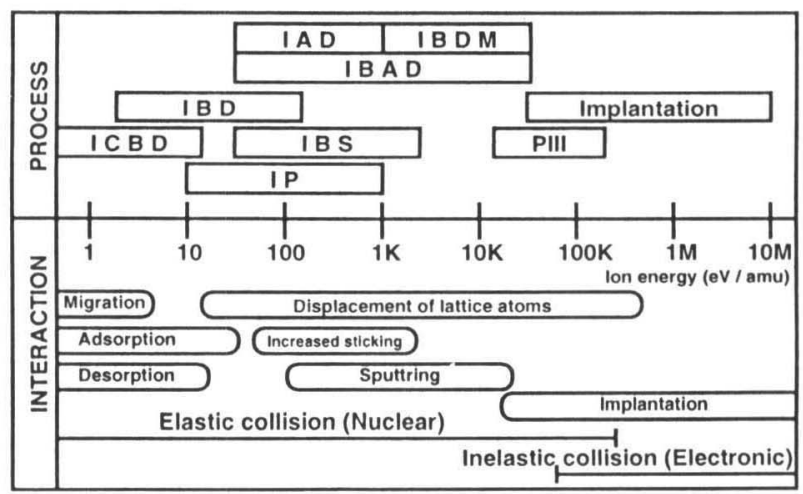

図 1 各種イオンピームプロセスと,関連するイオン-固体 相互作用。 


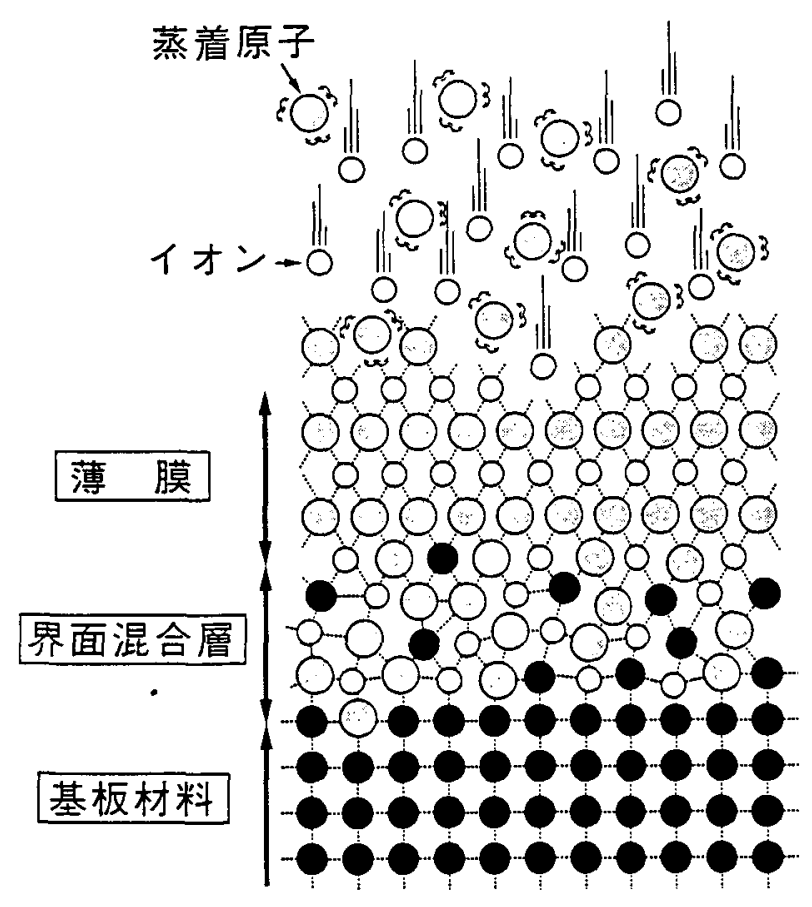

図 2 イオン照射を併用した成膜プロセスの概念図.

されている。さらに近年，プラズマ中に置かれた試料に 数 $10 \mathrm{kV}$ から数 $100 \mathrm{kV}$ の負のパルス高電圧を印可する ことによりイオン注入を行うプラス゚マ・イマージョン・ イオン注入法 (Plasma Immersion Ion Implantation, PIII， $\mathrm{PI}^{3}$ ) が開発され，特に複雑形状を有する工具ある いは機械部品等の母材改質における画期的な技術として 注目されている4).

これらの中で，膜成長と同時にイオンを照射しながら 薄膜を形成する IBAD 法あるいは各種の PVD 法におけ る薄膜形成プロセスの概念図を図 2 に示す。蒸着原子は 電子ビーム蒸着源あるいはスパッタリング等により供給 され,さらに薄膜の成長と同時に, IBAD 法ではイオ ンビーム源により，PVD 法では基板に印加された直流 の負バイアスあるいは高周波による自己負バイアスによ り，加速されたイオンが供給される，イオン照射により 成長膜に供給されるエネルギーは，蒸着物資の運動エネ ルギーに比べて格段に大きく，室温近傍の基板温度での 膜形成でも，表面拡散(あるいは表面マイグレーション) の促進による膜の均一性や緻密性の向上, 基板材料との 密着性の向上（界面混合層の形成，スパッタクリーニン グによる)，あるいは準安定化合物の合成, 結晶性の向上 ならびに相構造や配向性の制御等，機能性表面改質を行 う上で有利な効果が期待できる。これらの効果について は, Smidtによるレビュー5)に詳述されているので参照 されたい，また，基板への粒子入射角を適切に設定する ことにより，基板法線方向への選択配向性 (1 軸配向)の みならず面内の 2 軸配向性の制御が可能であることも示 されている6!. 特に後者の一例として, 斜入射の アルゴンー酸素混合イオンビームを併用した IBAD 法で YSZ 薄膜を合成することによりエピタキシャル関係を

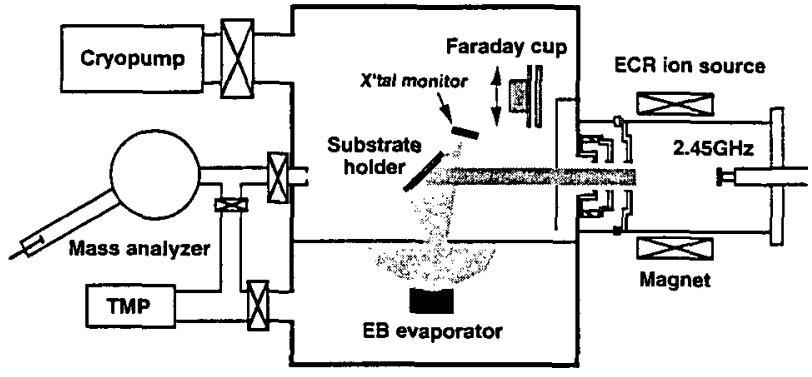

図 3 イオンビーム支援蒸着における装置構成の例.

満たさない非晶質基板上でも優れた面内配向性が得ら れ，その結果この YSZ 薄膜をバッファー層としてその 上に成長させたYBCO 系の高温超伝導薄膜において, 従 来よりも一桁以上高い臨界電流特性が実現されてい る7).

イオン照射を併用したこの成膜過程では,

[1] 基板に到達する蒸着原子供給束 $\left(v_{m}\right)$ に対するイ オン (あるいは加速粒子) 供給束 $\left(v_{i}\right)$ の比 (輸送比, $v_{i} /$ $\left.v_{m}\right)$ ，［2] イオンエネルギー，[3]各粒子の入射角， [4] 基板温度，[5] 成膜室内の気体分子の基板への衝突頻度 $\left(v_{g}\right)$ 等が, 薄膜の微細構造 (組成, 相, 結晶性, 配向性 等)とともにマクロな特性（トライボロジー，化学的特 性, 電気的特性, 光学的特性等) に影響を与える重要な プロセスパラメータとなる。

IBAD 法による成膜装置構成の一例を図 3 に示す ${ }^{8,99}$ 。 本装置は，無電極放電型 ECR バケットイオン源, 電子 ビーム蒸着源, 基板ホルダー（水冷）ならびに真空排気 系（クライオポンプ，夕ーボ分子ポンプ）から構成され ている、電子ビーム蒸着源による真空蒸着と同時にイオ ンを照射することにより成膜を行う，成膜室の到達真空 度は $10^{-7} \sim 10^{-6}$ Torr であるが，イオン源動作時はイオ ン源からのガス流入により $10^{-5} \sim 10^{-4}$ Torr となる。ま た, イオン電流測定用ファラデーカップ, 水晶振動子膜 厚モニター，および磁場偏向型イオン質量分析器を備え ている。

ここでは，これらの計測器による測定結果から上述の プロセスパラメータを評価する上での基本的な考え方に ついて以下にまとめ, 次節以降で各々の測定手法と評価 法について詳述する.

イオン源から基板に到達する加速粒子の供給束 $v_{1}$ [ions $\left./ \mathrm{cm}^{2} \mathrm{~s}\right]$ は,

$$
\begin{aligned}
v_{i} & =\frac{\alpha(1+\beta)}{e} J_{i} \\
& =6.24 \times 10^{18} \alpha(1+\beta) J_{i}\left[\mathrm{~A} / \mathrm{cm}^{2}\right] \quad\left[\mathrm{ions} / \mathrm{cm}^{2} \mathrm{~s}\right]
\end{aligned}
$$

で与えられ，主としてファラデーカップにより测定され るイオン電流密度 $J_{i}\left[\mathrm{~A} / \mathrm{cm}^{2}\right]$ で決定されるが, 基板に 到達するイオン種（原子イオン，分子イオン，多価イオ ン）ならびにイオン源から基板への輸送時における電荷 移行再結合によるビーム中性化を考慮する必要がある. そのための補正係数である $\alpha$ および $\beta$ は各々,イオン源 
から基板に供給される単位素電荷当たりの実効的な原子 数, および輸送過程での電荷移行再結合によるビーム中 性化の（測定されたイオン電流に対する）割合であり， その評価方法については次節で述べる。また, $e$ は素電荷 $\left(1.602 \times 10^{-19} \mathrm{C}\right)$ である.

一方, 電子ビーム蒸着源等から基板に到達する蒸着原 子供給束 $v_{m}$ [atoms $\left./ \mathrm{cm}^{2} \mathrm{~s}\right]$ は，水晶振動子膜厚モニター 等によりその場測定される蒸着速度 $R[\AA / \mathrm{s}]$ を用いて 評価されるとともに, 成膜時の蒸着源の制御にも用いら れる。

$$
\begin{aligned}
v_{m}= & R f_{t} \rho_{f}\left(M / N_{a}\right)^{-1} \\
= & 6.02 \times 10^{15}[\AA / \mathrm{s}] f_{t} \rho_{f}\left[\mathrm{~g} / \mathrm{cm}^{3}\right] / M[\mathrm{amu}] \\
& {\left[\text { atoms } / \mathrm{cm}^{2} \mathrm{~s}\right] }
\end{aligned}
$$

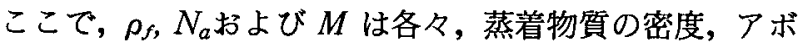
ガドロ数，および蒸着物質の原子量である。しかし，膜 厚モニターはイオン照射の影響を避けるため基板ホル ダーとは異なる場所に設置することが一般的であるう え, 基板と水晶振動子での付着係数ならびに膜の密度が 異なるため, 蒸着速度の計測值を実際の蒸着原子供給束 に対し較正して用いることが不可欠である。式 (2) に陽 に含まれている係数 $f_{t}$ は, このための補正係数で一般に ツーリング・ファクター (Tooling Factor) と称する。

さらに, 成膜中のガス䨌囲気から基板上へ単位面積・ 単位時間当たりに衝突する気体分子の頻度 $v_{\mathrm{g}}$ [molecules $/ \mathrm{cm}^{2} \mathrm{~s}$ ] は,

$$
\begin{aligned}
v_{g}= & p_{g}\left(2 \pi k_{B} T_{g} M_{g} / N_{a}\right)^{-1 / 2} \\
= & 3.51 \times 10^{22} \mathrm{p}_{g}[\text { Torr }]\left(T_{g}[K] M_{g}[\mathrm{amu}]\right)^{-1 / 2} \\
& {\left[\text { molecules } / \mathrm{cm}^{2} \mathrm{~s}\right] }
\end{aligned}
$$

により評価される。ここで, $p_{g}, T_{g}, M_{g}$ および $k_{B}$ は各々， 雾囲気ガス圧力, 雾囲気ガスの絶対温度, 気体の分子量, およびボルツマン定数である.特に酸素雲囲気において， チタン等の比較的反応性の高い金属の酸化物薄膜を合成 する場合，膜の組成ならびに構造に与える影響を考虑す る上で，イオンエネルギーあるいは式（1）および（2） から評価される翰送比と同等に無視できないプロセスパ ラメータである ${ }^{8,10)}$.

\section{3. 粒子供給束の計測手法と補正係数の較正}

\section{1 イオン奄流密度 $J_{i}\left[\mathrm{~A} / \mathrm{cm}^{2}\right]$}

基板上に照射されるイオンの供給束を評価するために は，基板に入射するイオン電流密度を正確に計測するこ とが必要である，ところが，加速された粒子が固体表面 に入射する場合，その表面からは，スパッタ原子， 2 次イ オン, 2 次電子等が放出され，これらの内特に，2次電子 放出に伴い見かけの電流測定值は実際のイオン流入量よ りも高い值に狂わされてしまう。すなわち，入射イオン 1 個当たりの 2 次電子放出比を $\gamma$ とすると, 2 次電子放 出による電流の寄与はイオン流入による電流方向と同じ であるため, 正味のイオン流入電流量の $(1+\gamma)$ 倍の值 となってしまう.この $\gamma$ 係数は, 気体放電における Tow- nsend の第 2 係数としても知られ，入射する固体表面の 状態 (仕事関数), イオン種およびエネルギーに依存する が, イオンエネルギーが $100 \mathrm{keV}$ 程度までの範囲ではエ ネルギーの增加と共に高い值を持つ傾向にある ${ }^{11,12)}$ 。こ のため, 基板ホルダー単体ての測定電流をそのままイオ ン電流とみなすことは極めて危険であり，2 次電子放出 の影響を抑制する機構を備えた電極系を構成して計測す る必要がある。通常, この目的のための電極系はファラ デーカップと呼ばれる.

このファラデーカップ構造の電流測定系の一例を図 4 に示す.「イオン電流検出電極」で放出される 2 次電子 は，負のバイアス（検出電極に対してー50〜-300 V)を 「2 次電子扣制電極」に印加して作られる電界により, 電 極系外部への流出が抑えられる。この際, 抑制電極の開 孔よりも十分に小さい開孔径を有する「イオンピーム制 限電極」を抑制電極の前面に設ける必要がある。これは, 抑制電極の開孔端に直接イオンビームが入射して発生す る 2 次電子による誤差を避けるためである。ここで,こ の制限電極の開孔は, 電流密度計測における面積のレ ファレンスを与える.さらに，抑制電極と検出電極へ流 入する電流の合計として正味のイオン電流が計測可能と なる.これは，検出電極から放出される 2 次粒子が抑制 電極に衝突して 2 次電子が放出されても，これらの電極 間で迷走する電流として相殺されるためである.

\section{2 単位素奄荷当たりの実効的原子数 $\alpha$}

イオン源プラズマあるいは各種 PVD 法におけるプロ セスプラズマ中では，一般に複数のイオン種（原子イオ ン, 分子イオン, 多価イオン, 負イオン) が生成する. IBD 法等のようにビーム輸送過程で質量分離して照射 する場合を除き，イオン照射効果を利用した多くの成膜 プロセス (IBAD 法, PVD 法等) では複数のイオン種が 同時に基板に照射されることになる。このため，基材へ 供給される加速粒子の算定に当たっては，上述のイオン 電流密度を単に素電荷で除したものとは異なり, 照射さ れるイオンの質量スペクトルあるいはイオンの価数を考 慮する必要がある。

荷電粒子として同一の電圧で加速されたイオンビーム を供給する場合，加速粒子の速度は（質量／価数）の平

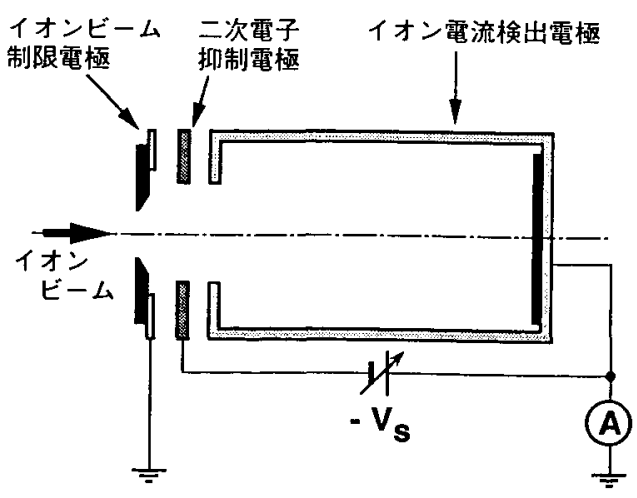

图 4 ファラデーカップ構造を用いたイオン電流密 度湘定系の例。 
方根に比例するため, 速度あるいは運動量の差異を利用 することにより質量／価数スペクトルの分析を行うこと が可能である。これらを利用した手法として，飛行時間 型分析器 (速度), ウィーンフィルターあるいはExB 型 分析器 (速度), 磁場偏向型質量分析器 (電気索量当たり の運動量) 等が用いられる ${ }^{13)}$.これらの分析手法の概念図 を図 5 に示す.

これらの分析手法により得られる筫量／価数スペクト ルを用いることにより, 単位素電荷に対する実効的原子 数 $\alpha$ は,

$$
\alpha=\Sigma\left(\frac{m}{z} \cdot J_{\mathrm{x}_{m}}^{z+}\right) /\left(J_{\mathrm{x}_{m}}^{z+}\right)
$$

で見積もることが可能である，ここで， $\mathrm{m}, z$ ，および $J$ ${ }_{x_{m}}^{z+}$ は, イオン種 $\mathrm{X}_{m}^{z+}$ を構成する原子の数, 価数, および 電流量である。磁場偏向型質量分析器を用いて, 図 3 の 成膜装置で計測した窒素イオンビーム（加速電圧, 20 $\mathrm{kV})$ の質量/価数スペクトルの一例を図 6 に示す.この 例では, 分子イオン $\mathrm{N}_{2}{ }^{+}$が $73.6 \%$, 原子イオン $\mathrm{N}^{+}$が 22.5\%,2 価のイオン $\mathrm{N}^{2+}$ が $3.9 \%$ であ, 単位素電荷当た り 1.72 個の窒素原子が加速粒子として基板に供給され ることがわかる。

\section{3 電荷移行再結合 $1+\beta$}

イオン源から引き出されたイオンビーム $\mathrm{X}^{+}$は, 基板表 面までの輸送過程で成膜室内の中性原子(気体分子ある いは蒸着原子) B との衝突相互作用で, 電荷移行による再 結合 ${ }^{13)}$ が起こると，中性化した加速粒子としてふるまう。

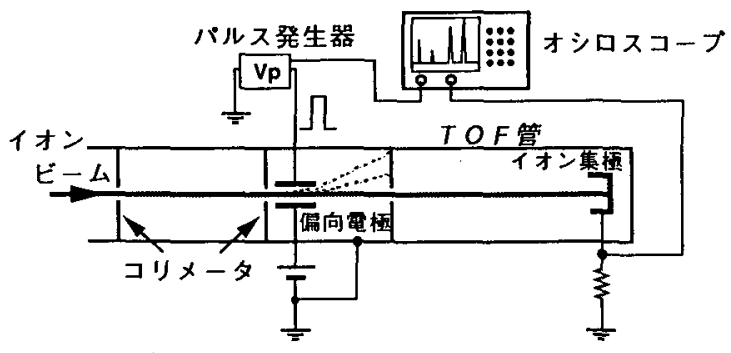

（a）飛行時間型質量分析器

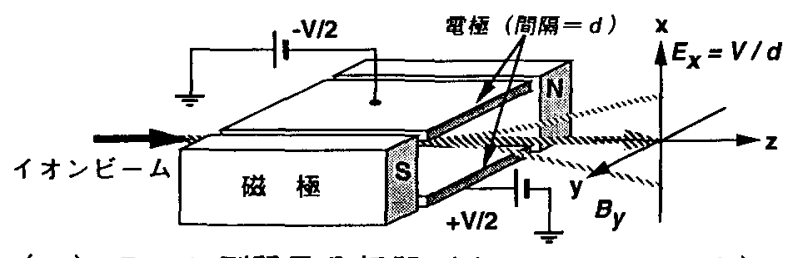

（b） $E \times B$ 型質量分析器（ウィーンフィルタ）

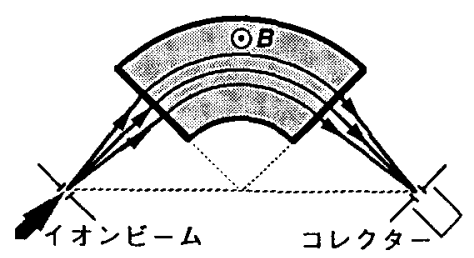

(c) 磁場偏向型質量分析器

図 5 質量分析系の概念図。これらの分析系はいずれも， 同一電压で加速されたイオン種に対し, 質量/価数 の分離を行うことが可能である.

$$
\begin{aligned}
& \mathrm{X}^{z+}+\mathrm{B} \rightarrow \mathrm{X}^{(z-1)+}(n, l)+\mathrm{B}^{+} \\
& \mathrm{X}^{z+}+\mathrm{B} \rightarrow \mathrm{X}^{(z-1)+}(n, l)+\mathrm{B}^{+}+h v
\end{aligned}
$$

この電荷移行衝突の前後で, イオンと原子の内部エネ ルギーの和が式 (5) のように保存されるものを「共鳴型 電荷移行」, 式 (6) のように発光 $(h v)$ 等により内部エネ ルギーが保存されないものを「非共鳴型電荷移行」とい う. 低エネルギー領域での全断面積 $\sigma_{z, z-1}$ は種々の経験 式があるが，その一例として Müller and Salzborn ${ }^{14)} に$ より,

$$
\sigma_{\mathrm{z}, \mathrm{z}-1} \approx 1.43 \times 10^{-12} \mathrm{z}^{1.17} \mathrm{I}^{-2.76} \quad\left[\mathrm{~cm}^{2}\right]
$$

と与えられている。ここでは，Iは標的 B の電離エネル

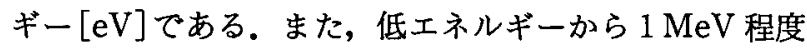
までのイオンに対する共鳴型電荷移行断面積に関して

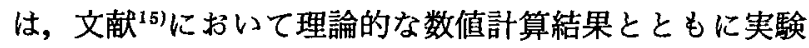
值との詳しい比較がなされているので参照されたい.

ファラデーカップによる電流密度测定值から算定した 荷電粒子束に対する, 本来イオン源から供給される加速 粒子束の総量（荷電粒子十電荷移行再結合による中性化 粒子) の比を評価するための補正係数 $(1+\beta)$ は

$$
1+\beta=\exp \left(\sigma_{z, z-1} L p_{g} / k_{B} T_{g}\right)
$$

により与えられる.ここで, $L, p_{g}, T_{g}$ は各々, イオン源 の引出し電極から基板表面までの距離, 成膜室内の気体 圧力，気体の絶対温度である。また，式 (8) で与えられ る量の逆数は, イオン源から中性化されることなく荷重 粒子として輸送されるビーム透過率となっていることに 注意されたい.一例として， $L=50 \mathrm{~cm}$ の場合における， $5 \mathrm{kV}$ の電圧で加速された $\mathrm{Ar}^{+}$インの透過率の Ar 圧 力依存性を図 7 に示す。

補正係数 $(1+\beta)$ を実験的に較正する方法として,イ オン源の動作パラメータを一定に保ったままで, 排気系 のコンダクタンスを制御することにより成膜室の気体圧 力を変化させて, イオン電流を計測する手法を用いるこ

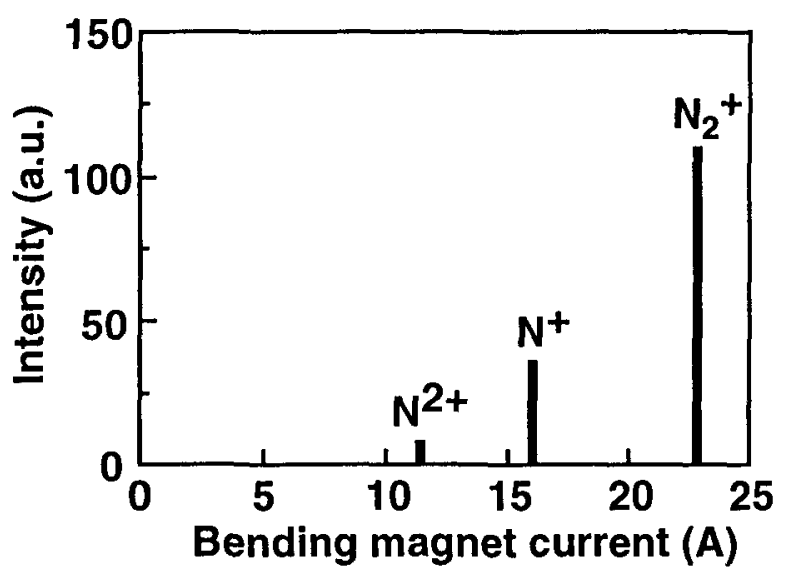

図 6 磁場偏向型質量分析器を用いて計測した，加速電压 $20 \mathrm{kV}$ で引き出された窒素イオンビームの質量スペ クトルの例. 


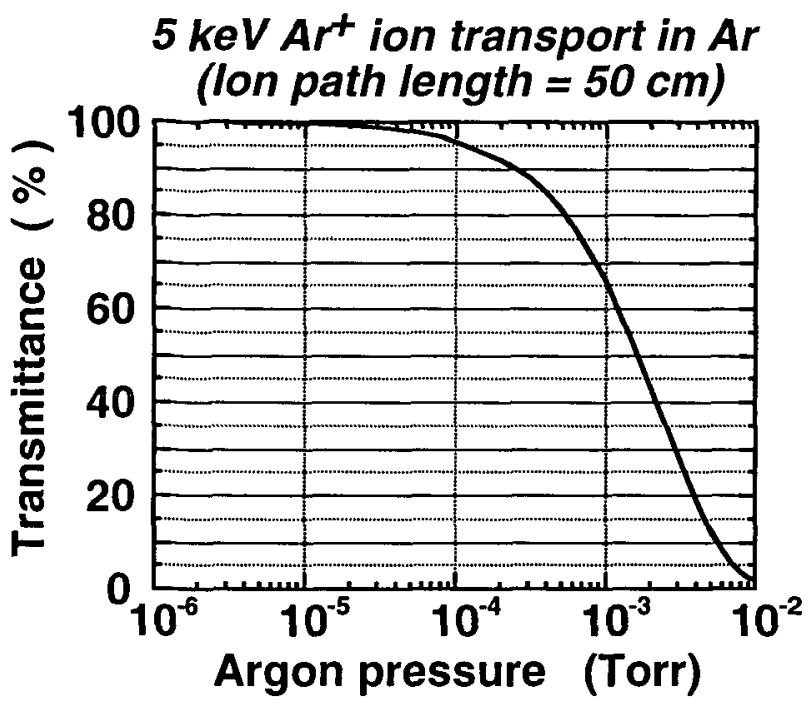

図 7 エネルギー5 $\mathrm{keV}$ の $\mathrm{Ar}^{+}$イオンがアルゴン気体中を $50 \mathrm{~cm}$ 走行する場合における，電荷移行再結合を考虑したイオン 透過率のアルゴン区力传存性。

とも可能である，この場合，対数表示したイオン電流の 計測值を気体圧力に対しプロットした直線の傾きから， 式 (8) を用いることによりこの補正係数の直接測定が可 能である。

3.4 蒸着におけるッーリング・ファクター $f_{t}$

成膜中に電子ビーム蒸着源あるいはスパッタリング源 から基板に供給される蒸着原子束の測定には, 水晶振動 子膜厚モニター16)を用いることができる.しかし,第 2 節 で述べたように，膜厚モニターと基板とで，蒸着源に対 する空間的配置ならびに振動子への付着俰数は一般に異 なる.このため, 膜厚モニターによる成膜速度の表示に 対する基板への蒸着原子供給束の比(ツーリング・ファ クター, $\left.f_{t}\right)$ を較正することが不可欠である。

ツーリング・ファクターの較正は以下の手順で行うこ とができる．まず，基板ホルダーに設置したテスト基板 上に，蒸着源のみを用いて（イオン照射を遮断した状態 で）成膜を行う. 次いで, 蒸着物質を成膜した薄膜の面 密度 $\left(\rho_{t} X_{t}\right)$ を測定する， $X_{t}, \rho_{t}$ は，テス卜膜の膜厚なら びに密度である.これにより，ッーリング・ファクター fは,

$$
f_{t}=\left(\rho_{t} X_{t} / \Delta t\right) / R_{\rho_{f}}
$$

で与えられる。ここで, $\Delta t, R$ ，および $p_{t}$ は，テスト膜の 成膜時間, 膜厚モニターによる平均成膜速度の表示値, および蒸着物質の密度である。

テスト膜の面密度は，ラザフォード後方散乱 (RBS) 等を用いることにより精度よく計測することが可能であ る.ラザフォード後方散乱法の概念図を図 8 に示す。テ ス卜膜の面密度 $\left(\rho_{t} X_{t}\right)$ と後方散乱による検出収量 $(Y)$ との関係は,

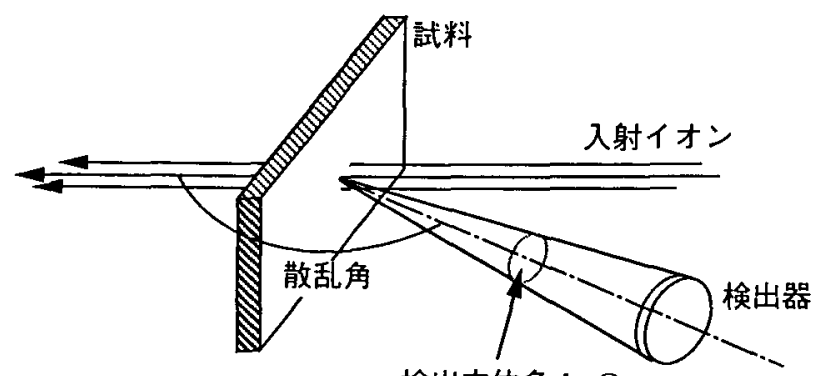

検出立体角： $\Omega$

図 8 ラザフォード後方散乱法に枋ける実験配置の概念図。

$$
Y=\sigma_{s}\left(\frac{\Omega}{4 \pi}\right) Q \rho_{\mathrm{t}} X_{\mathrm{t}}\left(M / N_{a}\right)^{-1}
$$

で与えられる。ここで， $\sigma_{s}, \Omega[s r] ， Q$ は，ラザフォー ド散乱における平均微分散乱断面積, ステラジアン単位 の検出立体角, ビーム中の入射粒子の総数である。

\section{4. おわりに}

イオン照射を用いた薄膜形成におけるプロセスパラ メータについて，計測・評価ならびに較正における基本 的な概念と手法を述べた。ここで述べたイオン照射効果 のみならず,光および各種ラジカルの照射を併用した「非 平衡活性場」の構築と新しい機能性表面改質法の研究が ますます重要になりつつあることを付記しておく，本稿 が、これからこの分野の研究に入られる方々の一助にな れば幸いである。

\section{参考文 献}

1) T. A. Friedmann, P. B. Mirakami, D. L. Medlin, K. F McCarty, E. J. Klaus, D. R. Boehme, H. A. Johnsen, M. J. Mills, D. K. Ottesen, and J. C. Barbour: J. Appl. Phys. 76 (1994) 3088.

2) Y. Setsuhara, T. Suzuki, Y. Tanaka, S. Miyake, M. Suzuki, M. Kumagai, K. Ogata, M. Kohata, K. Higeta, T. Einishi, Y. Suzuki, Y. Shimoitani, and Y. Motonami: Nucl. Instr. Meth. in Phys. Res. B. 127/128 (1997) in press.

3) 三宅正司：高温学会会誌 18 (1992) 122.

4) R. Hutchings, G. A. Collins and Y. Tendys: Surf. Coat. Technol. 51 (1992) 489.

5) F. A. Smidt: Int. Mat. Rev. 35 (1990) 61.

6) W. Ensinger: Surf. Coat. Technol. 65 (1994) 90.

7) Y. Iijima, N. Tanabe, O. Kohno and Y. Ikeno: Appl. Phys. Lett. 60 (1992) 769.

8) S. Miyake, K. Honda, T. Kohno, Y. Setsuhara, M. Satou and A. Chayahara: J. Vac. Sci. and Technol. A 10 (1992) 3253 .

9) Y. Setsuhara, H. Ohsako, Y. Makino and S. Miyake: Surf. Coat. Technol. 66 (1994) 495.

10) Y. Setsuhara, H. Aoki, S. Miyake, A. Chayahara and M. Satou: Nucl. Instr. Meth. in Phys. Res. B. 80/81 (1993) 1406.

11）武田 進：気体放電の基礎（東明社，1973）.

12) 石川順三 :イオン源工学（アイオニクス株式会社, 1986).

13）プラススマ核融合学会編：プラスマ診断の基礎 (名古屋大学出 版会, 1990).

14) A. Muller and E. Salzborn: Phys. Lett. 62 A (1977) 391.

15) S. Sakabe and Y. Izawa: Atomic Data and Nucl. Data Tables 49 (1991) 257.

16) C. LU and O. Lewis, J. Appl. Phys. 43 (1972) 4385 